\title{
Update on prenatal diagnosis and fetal surgery for myelomeningocele
}

\author{
César Meller, M.D. ${ }^{a}$, Delfina Covini, M.D. ${ }^{b}$, Horacio Aiello, M.D. ${ }^{a}$, \\ Gustavo Izbizky, M.D. ${ }^{a}$, Santiago Portillo Medina, M.D. ${ }^{c}$ and Lucas Otaño, M.D. ${ }^{a}$
}

\begin{abstract}
A seminal study titled Management of Myelomeningocele Study, from 2011, demonstrated that prenatal myelomeningocele defect repaired before 26 weeks of gestation improved neurological outcomes; based on this study, fetal surgery was introduced as a standard of care alternative. Thus, prenatal myelomeningocele diagnosis within the therapeutic window became a mandatory goal; therefore, research efforts on screening strategies were intensified, especially in the first trimester. In addition, different fetal surgery techniques were developed to improve neurological outcomes and reduce maternal risks. The objective of this review is to provide an update on the advances in prenatal screening and diagnosis during the first and second trimesters, and in open and fetoscopic fetal surgery for myelomeningocele.

Key words: myelomeningocele, fetal therapies, spina bifida, fetoscopy, antenatal care.
\end{abstract}

http: / / dx.doi.org/10.5546/ aap.2021.eng.e215

To cite: Meller C, Covini D, Aiello H, Izbizky G, et al. Update on prenatal diagnosis and fetal surgery for myelomeningocele. Arch Argent Pediatr 2021; 119(3):e215-e228.

a. Department of Obstetrics.

b. Department of Imaging Studies.

c. Department of Pediatric Neurosurgery. Hospital Italiano de Buenos Aires, Autonomous City of Buenos Aires, Argentina.

E-mail address: César H. Meller, M.D.: cesar.meller@ hospitalitaliano.org.ar

Funding:

None.

Conflict of interest:

None.

Received: 9-29-2020 Accepted: 11-12-2020

\section{INTRODUCTION}

Until 2011, prenatal screening and diagnosis strategies regarding myelomeningocele were aimed at providing appropriate counseling to parents based on prognosis so that they were aware of management options, either adequate obstetric follow-up and delivery in a center with neonatal surgery availability or, depending on local laws, an abortion. ${ }^{1,2}$ A seminal study titled Management of Myelomeningocele Study (MOMS) ${ }^{3}$ demonstrated that prenatal myelomeningocele repair before 26 weeks of gestation improved neurological outcomes; based on this study, fetal surgery was introduced to standard of care alternatives for myelomeningocele management., ${ }^{2,4-7}$
This powered research in two critical areas. On the one side, prenatal myelomeningocele diagnosis within the therapeutic window became a mandatory goal; therefore, research efforts on screening strategies were intensified, especially in the first trimester. On the other side, different fetal surgery techniques were assessed to improve neurological outcomes and reduce maternal risks. The objective of this review is to provide an update on the advances in prenatal screening and diagnosis and in fetal surgery for myelomeningocele.

\section{EPIDEMIOLOGY}

The prevalence of spina bifida varies markedly worldwide based on ethnic and geographic characteristics. ${ }^{8,9}$ In Argentina, since the implementation of the law for flour fortification with folic acid, spina bifida prevalence decreased approximately $60 \%$. Nowadays, it is approximately 1 in every 2000 live births. ${ }^{10}$ Its prevalence during pregnancy is higher and decreases towards the end due to intrauterine death caused by this disease, especially in syndromic cases. ${ }^{11}$

Most myelomeningocele cases occur as a single defect. Some abnormalities are considered part of the disease spectrum and, therefore, it is still considered an isolated defect, such as ventriculomegaly, Arnold-Chiari II malformation, hypoplasia of the corpus callosum, and talipes equinovarus., ${ }^{2,10-12}$

\section{PRENATAL SCREENING AND DIAGNOSIS OF MYELOMENINGOCELE}

Prenatal spina bifida detection has increased in recent decades, and it is now possible to do it in the 
first trimester. The European Surveillance of Congenital Anomalies (EUROCAT) reported, for the 2012-2017 period, a prenatal sensitivity close to $90 \%$, i.e., in approximately $10 \%$ of cases, ultrasounds were wrongly classified as normal (false negative result). ${ }^{13}$ In turn, in regions with fewer resources, such as Latin America, prenatal detection is not as common and it is done at a more advanced gestational age. ${ }^{8,14}$

In the 1970s, spina bifida was diagnosed by ultrasound in the prenatal period for the first time $\mathrm{e}^{15}$ and maternal blood alpha-fetoprotein levels were added to second trimester screening tests. ${ }^{16}$ The biochemistry panel is practically not used anymore; screening and diagnosis are currently usually done in the second trimester and, more recently, also during the 11-14-week ultrasound. ${ }^{17-19}$

\section{Second-trimester ultrasound}

1.a. Direct spinal assessment: this is done as part of a routine, detailed ultrasound around week 18-24. The International Society of Ultrasound in Obstetrics \& Gynecology (ISUOG) suggests re-assessing the spine using axial, sagittal, and coronal sections (Figure 1). ${ }^{20,21}$ The direct signs of spina bifida aperta include visualizing the bone defect and the sac protrusion (meningocele or myelomeningocele) (Figure 2).
It may be technically difficult to find them, such as when the fetus is back-to-back (with the spine away from the probe) or with the spine against the placenta or uterus. Therefore, it is critical to be aware of the indirect signs of spina bifida, which had been described in the 1980s and became the true pillars of myelomeningocele screening. ${ }^{22}$

1.b. Assessment of intracranial signs of spina bifida: indirect cranial signs work for screening and help to diagnose spina bifida. They include, during the second trimester, a smaller biparietal diameter (BPD) and head circumference, flattened or concave frontal bones ("lemon sign"), ventriculomegaly, obliteration of the cisterna magna, and visualization of cerebellar abnormalities, including the absence of cerebellum in the posterior fossa, a small cerebellum or anterior concave shape ("banana sign") (Figure 3). ${ }^{23}$ In fetus with myelomeningocele at less than 24 weeks of gestation, the "lemon sign" is almost invariably present $(98 \%)$, and the "banana sign" is observed in 70-80\% of cases; however, in fetuses with an older gestational age, the "lemon sign" is uncommon and, in the posterior fossa, the most common finding is an absent cerebellum due to the downward displacement through the foramen magnum. ${ }^{11,23,24}$ A smaller head size, with a BPD or head circumference below the $5^{\text {th }}$ percentile, also

FIGURE 1. a) Sagittal section, b) axial section, c) coronal section, and d) 3D reconstruction of a normal spine at 20 weeks of gestation
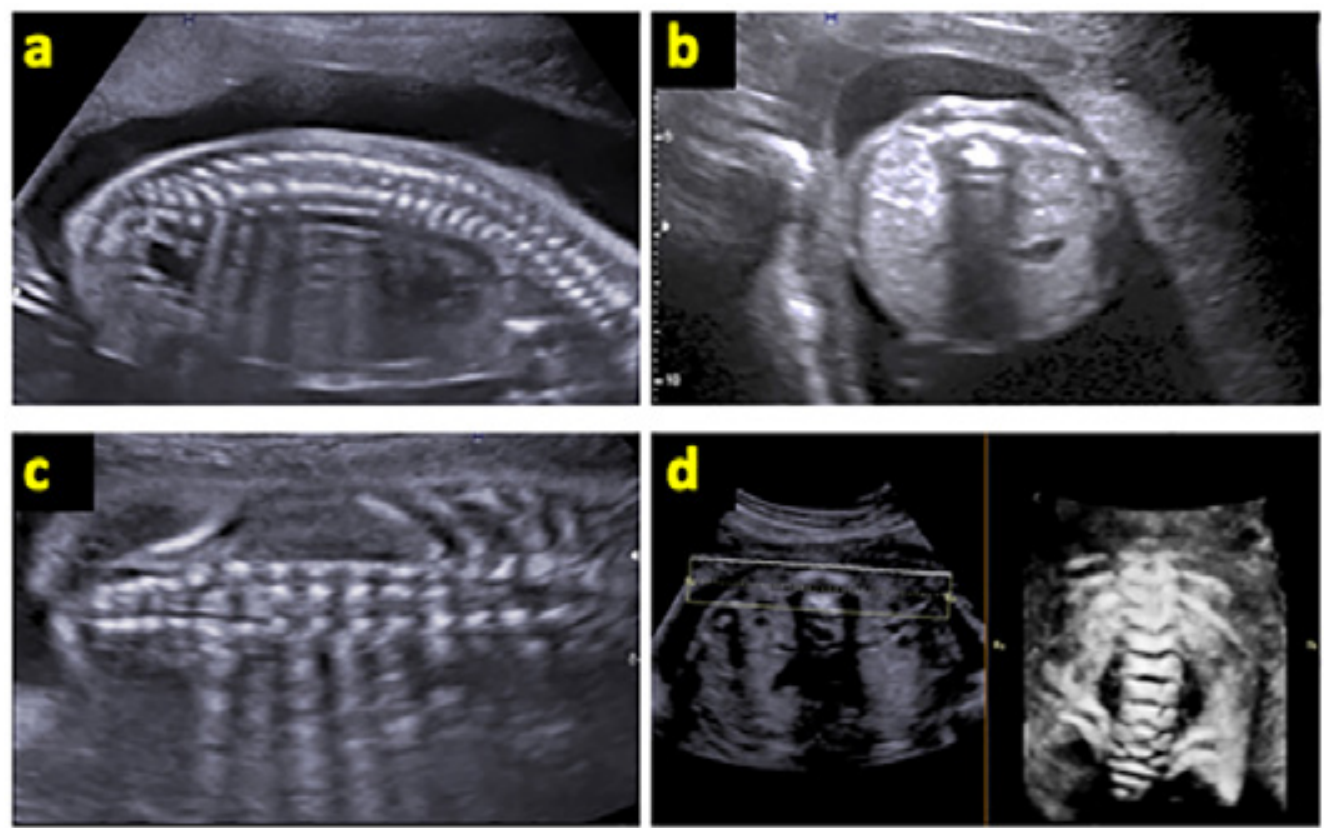
tends to normalize towards the third trimester, ${ }^{11}$ whereas ventriculomegaly (atrium $>10 \mathrm{~mm}$ ) tends to progress throughout gestation, both in fetuses receiving routine treatment and those undergoing prenatal surgery. ${ }^{11,25}$

\section{First-trimester ultrasound}

2.a. Direct spinal assessment: although it is possible to make a prenatal diagnosis based on direct visualization at 11-14 weeks, it is extremely difficult. ${ }^{26}$ Therefore, intracranial indirect signs have been described.

2.b. Assessment of intracranial signs: while measuring nuchal translucency (NT), it is possible to assess whether the posterior fossa is normal (Figure 4). Our group recently published a bibliographic review of spina bifida aperta detection in the first trimester, which provided details on the multiple intracranial indirect signs described, both in mid-sagittal and

FIGURE 2. Direct signs of spina bifida aperta. a) Sagittal section and b) axial section showing a spinal defect through which the meningeal sac protrudes (arrows). c) Coronal section showing the separation of lateral processes of lumbar vertebrae
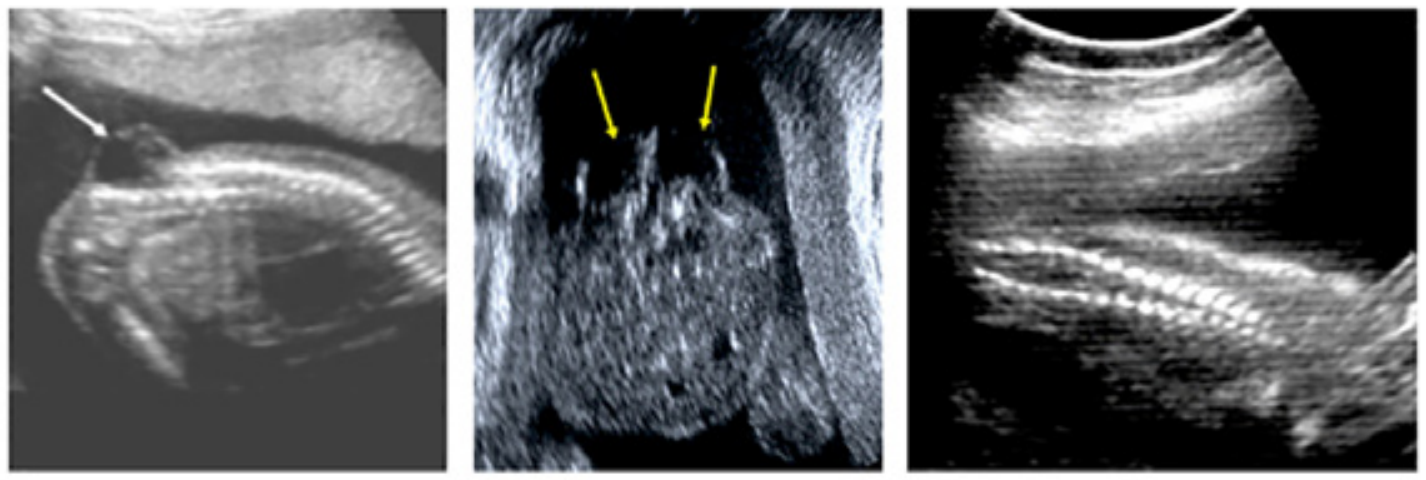

FIGURE 3. a) Transverse section of the cephalic pole showing the posterior fossa of a normal fetus at 21 weeks of gestation: note the skull ovoid shape, the anterior complex made up of the anterior horns of the lateral ventricles and the cavum septum pellucidum (CSP) and, in the posterior fossa, the butterfly-shaped cerebellum and the presence of the cisterna magna. b) Twenty-week fetus with lumbosacral spina bifida aperta: ventriculomegaly $\left({ }^{*}\right)$ and concave frontal bone (thin arrows) shaping the skull in a particular manner (lemon sign). c) Image of posterior fossa of a 20-week fetus with myelomeningocele: obliteration of the cisterna magna caused by an abnormal cerebellum position and shape, showing posterior convexity (thick arrows), known as the banana sign.
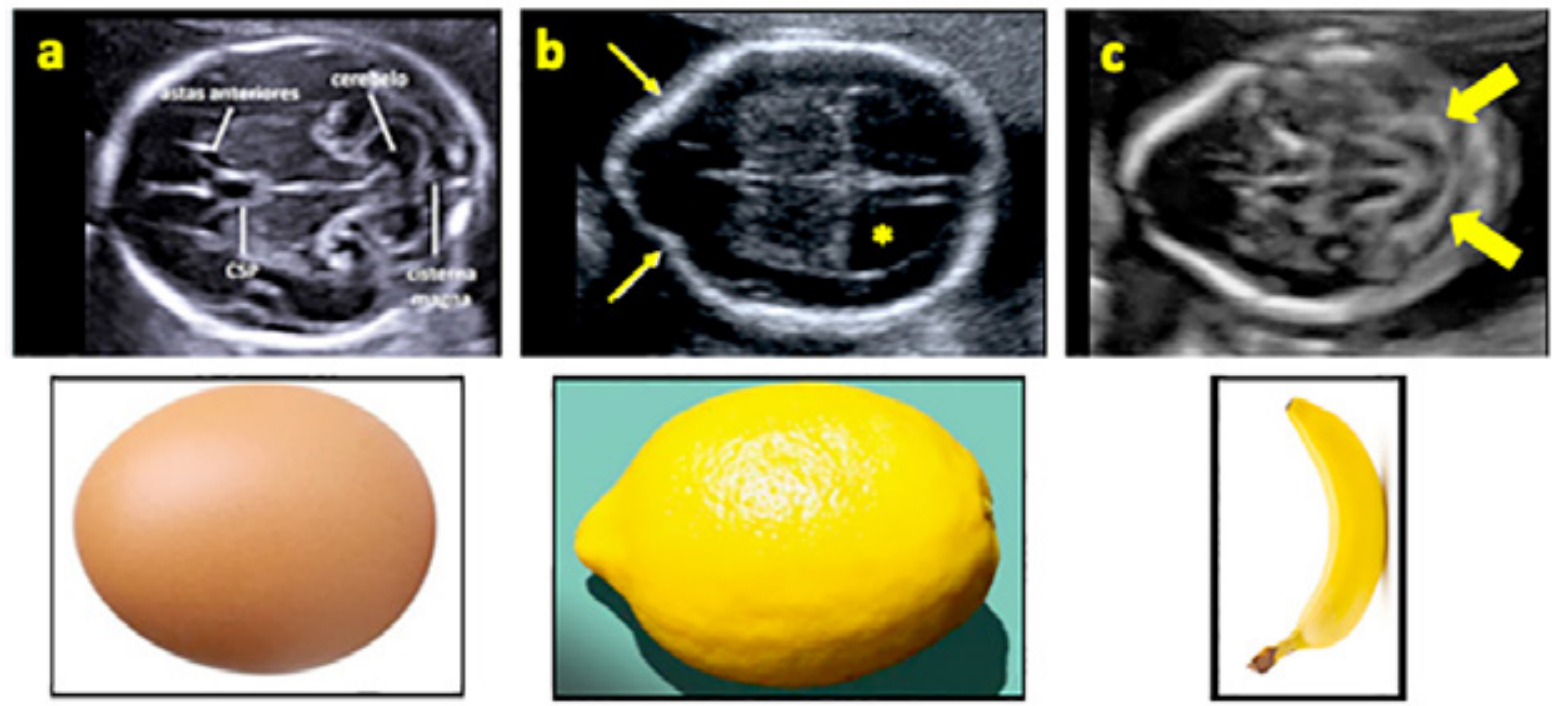
axial sections. ${ }^{26}$ The assessment of the posterior fossa may detect abnormalities such as reduced or absent intracranial translucency (or fetal fourth ventricle $)^{17,27}$ or cisterna magna, ${ }^{17,27,28}$ or an abnormal relationship between the brainstem and the distance between the brainstem and the occipital bone (Figure 5). This space may be analyzed based on measurements or by simply looking at the 4 echogenic lines defining the 3 hypoechoic spaces. ${ }^{26-27,29-31}$ Abnormalities in axial sections include observation of the "lemon sign;" 27,32 reduced BPD ${ }^{33,34}$ and its relationship with transverse abdominal diameter, if this is $<1$, it detects approximately $70 \%$ of fetal myelomeningocele cases with a $5 \%$ false positive rate; ${ }^{35}$ or the visualization of the ventricular system with a "dried up" appearance; ${ }^{19,36}$ or different measurements resulting from the posterior displacement of brain structures. 37,38

These signs have a variable performance across studies and among observers. ${ }^{26}$ However, using the same mid-sagittal section of the NT and while examining the posterior fossa "at first sight," it may be possible to detect most myelomeningocele cases. ${ }^{24,26}$

\section{PRENATAL DIAGNOSTIC EVALUATION OF MYELOMENINGOCELE}

If myelomeningocele is suspected in the prenatal period, the diagnostic assessment should be completed in the first place; then, counseling and management alternatives should be provided, which include postnatal surgery, prenatal surgery in selected cases or, depending on local laws, abortion. ${ }^{1,2}$ As with other congenital anomalies, it is critical to establish if it is an isolated defect or in combination with other type

FIGURE 4. a) Mid-sagittal section of a normal fetus showing nuchal translucency (TN), diencephalon (D), and mesencephalon (M). b) Four echogenic lines (yellow) defining the 3 hypoechoic spaces: brainstem (TE), fourth ventricle or intracranial translucency (TI), and cisterna magna (CM)
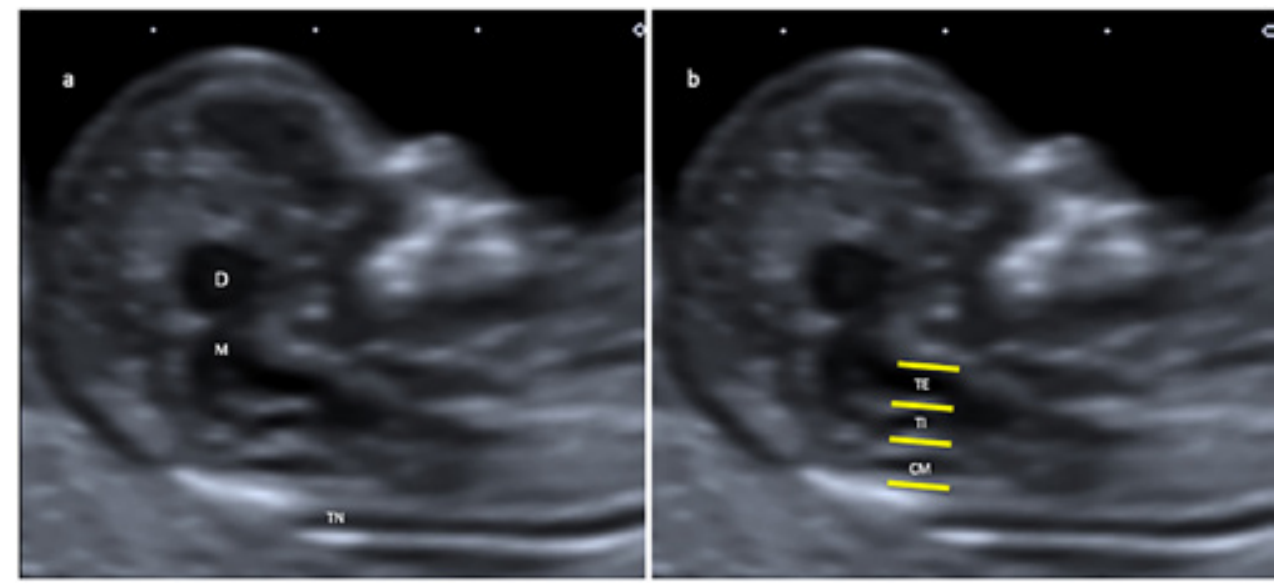

FIGURE 5. a) Direct observation of spina bifida aperta (arrow) in a 12-week fetus and b) posterior fossa showing only 2 hypoechoic spaces, instead of 3 , the brainstem (1) and the fourth ventricle/cisterna magna (2)
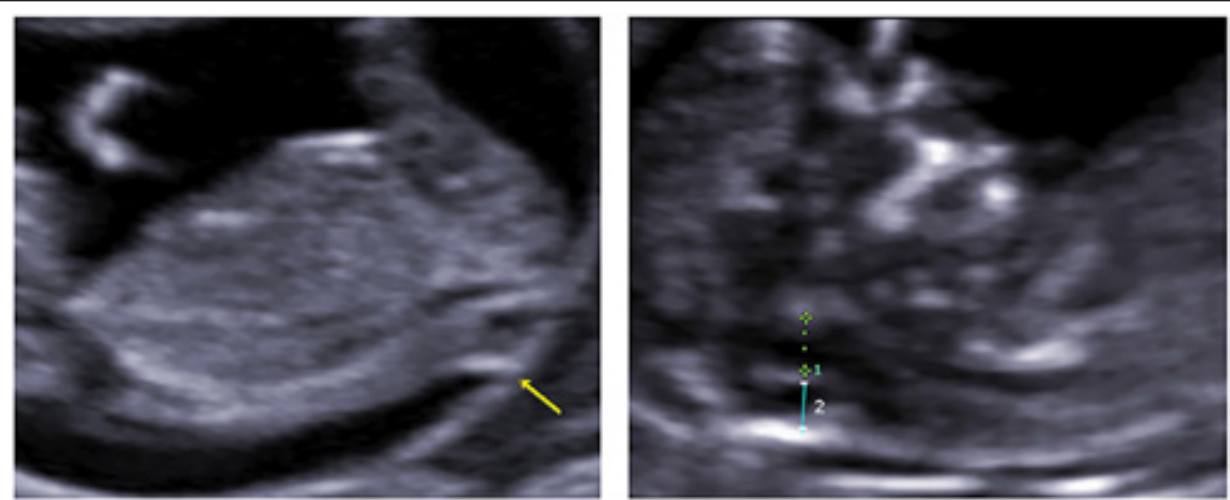
of defect or if it is part of a genetic syndrome, so detailed imaging tests and genetic assessments are required.

a. Genetic assessment: between $5 \%$ and $20 \%$ of myelomeningocele cases have chromosomal abnormalities. The most common one is trisomy $18 .^{1,12,39,40}$

The inclusion criteria of all fetal surgery programs mention, at least, a normal standard karyotyping or quantitative fluorescence polymerase chain reaction (QF-PCR). Some centers also request a normal microarray analysis, ${ }^{2,41}$ a technique that is limited in our setting due to its high cost and low availability.

b. Imaging tests: these include a detailed morphology scan, a fetal echocardiogram, and, if available or if the patient is a candidate for fetal surgery, fetal magnetic resonance imaging (FMRI).

The detailed scan would allow to rule out associated malformations and kyphosis, and to determine the anatomical and functional levels of the lesion. The lower the defect, the better the prognosis (Table 1). ${ }^{42}$ The anatomical level is based on the highest level of the bone defect and is established via ultrasound (Figure 6) and/or FMRI. Motor function level is mainly defined by ultrasound based on the assessment of hip, knee, and ankle/foot mobility, similar to a postnatal neurological assessment (Table 1). ${ }^{42}$

Another aspect that may be assessed with an ultrasound and FMRI is the presence and size of ventriculomegaly. If it is severe $(\geq 15 \mathrm{~mm})$, it is a predictor of hydrocephalus and ventriculoperitoneal shunt (VPS) requirement, even in fetuses undergoing intrauterine surgery. ${ }^{25}$

An FMRI allows to detect other associated intracranial abnormalities and also to assess and establish the size of cerebellar and brainstem herniation through the foramen magnum (Sutton grading) (Figure 7). ${ }^{43}$ Finally, the cervix length should be measured as an indicator of risk for preterm birth $(<20 \mathrm{~mm}$ is an exclusion criterion for fetal surgery).

TABLE 1. Determination of the lesion's motor function level

\begin{tabular}{lcc}
\hline Level & Function & Prognosis for ambulation and type of orthosis required \\
\hline L1-L2 & $\begin{array}{c}\text { Hip: flexion and adduction } \\
\text { L3 }\end{array}$ & $\begin{array}{c}\text { Indoor ambulation with knee-ankle-foot } \\
\text { orthoses and crutches }\end{array}$ \\
L4 & Knee: extension & $\begin{array}{c}\text { Community ambulation with ankle-foot orthoses, } \\
\text { with or without crutches }\end{array}$ \\
L5 & Knee: flexion & $\begin{array}{c}\text { Ankle/foot: dorsal flexion } \\
\text { S1 }\end{array}$ \\
\hline
\end{tabular}

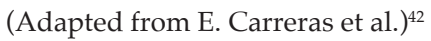

FIGURE 6. Determination of the lesion's anatomical level in a 22-week fetus with spina bifida aperta. To establish the height of the lesion, you may start from the caudal region (a), knowing that, in the second trimester, the last ossified vertebra in the fetus is S4, or (b) from the last thoracic vertebra, which may be recognized by the presence of the last rib (arrow). In this example, the defect starts approximately in L4.
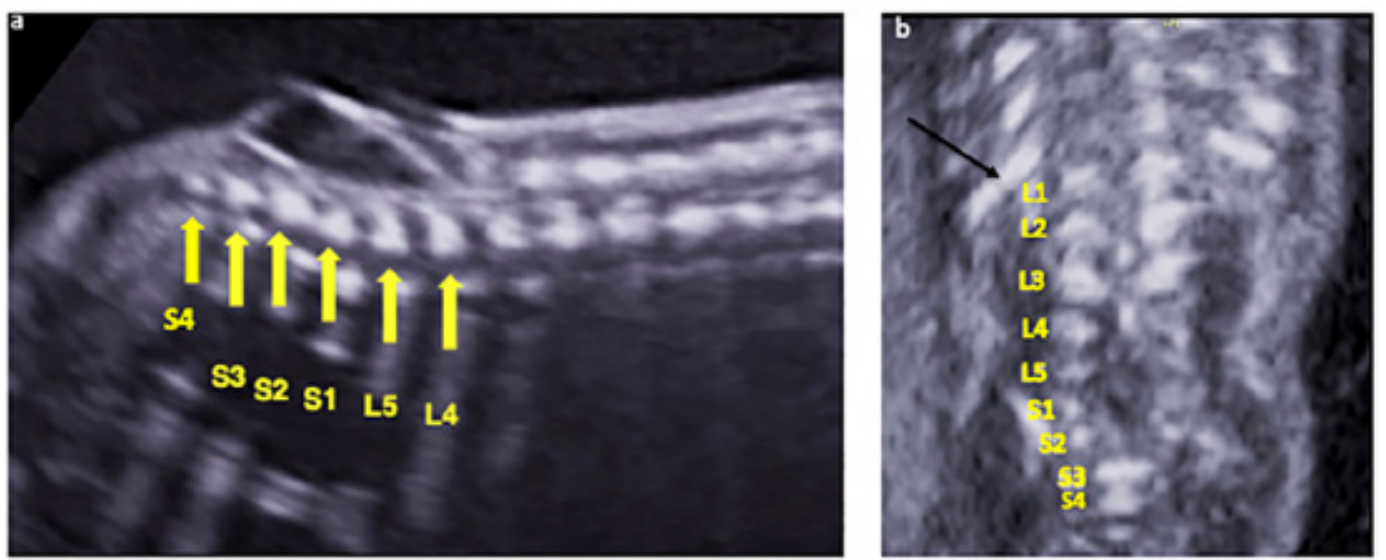
FIGURE 7. Sagittal sections of fetal magnetic resonance imaging showing the grading system of Sutton et al. of brainstem and cerebellar herniation in relation to the foramen magnum (yellow line). A. Grade 0: normal. B. Grade 1: visible fourth ventricle and cisterna magna, without cerebellar displacement below the foramen magnum. The tentorium could be vertically oriented, and tectal beaking could be present. C. Grade 2: visible cisterna magna without displacement of the cerebellum below the foramen magnum. The fourth ventricle is not visible. D. Grade 3: displacement of the cerebellum below the foramen magnum and obliteration of cerebrospinal fluid spaces in the posterior fossa. The tip of the arrow points to the lower limit of the cerebellar tonsils.
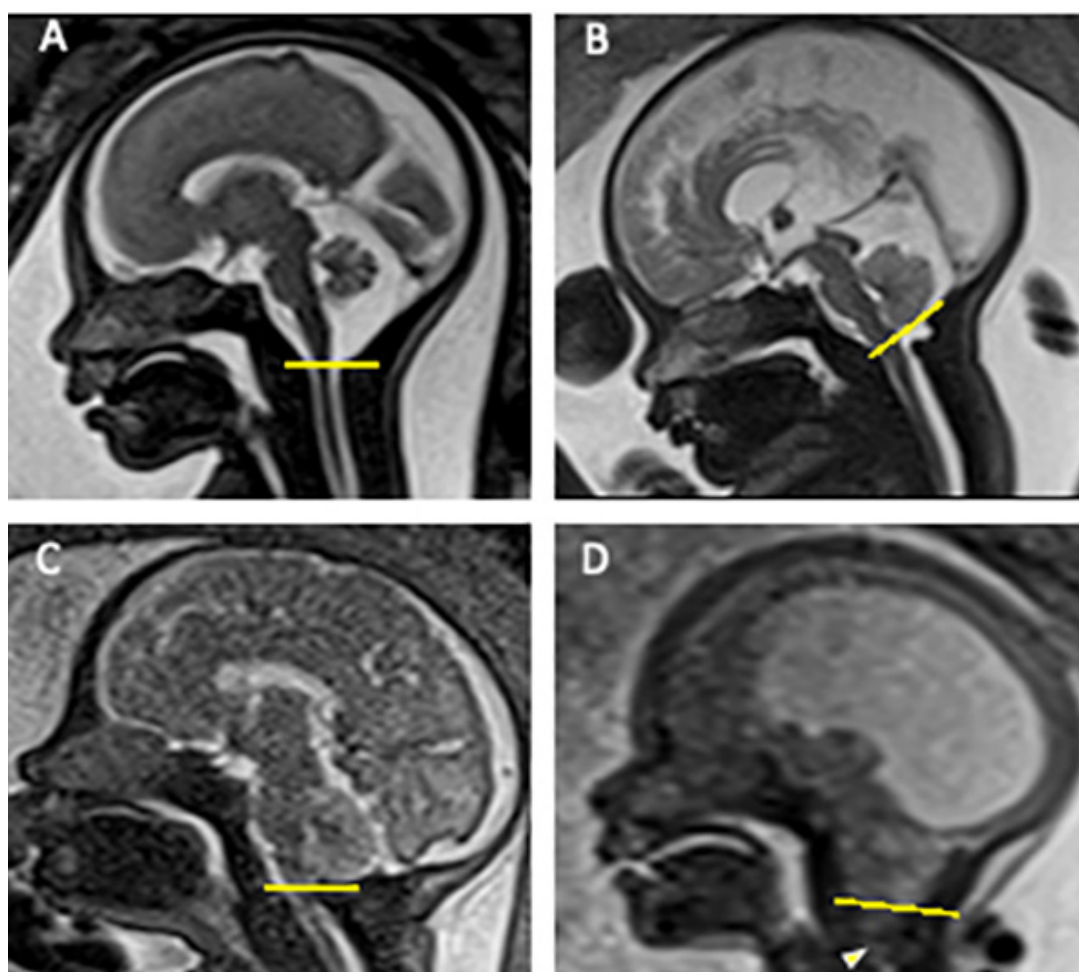

FIGURE 8. Pros and cons of open fetal surgery for myelomeningocele compared to postnatal surgery (MOMS and MOMS2)
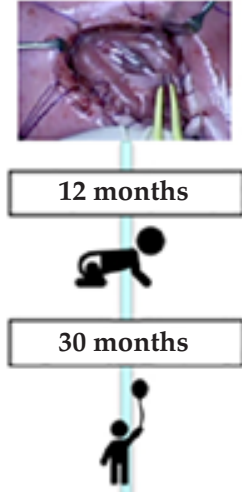

5-10 months

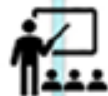

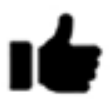

Lower rate of:

- VPS

- Chiari II malformation

Improvement in:

- Motor function of lower limbs

- Independent ambulation

- Psychomotor development

- Lower requirement for intermittent urinary catheter

- Voluntary urination $24 \%$ versus

$4 \%$ postnatal surgery $(\mathrm{p}<0.001)$

- Greater independent mobility and functioning

- Lower rate of Chiari II malformation

$(60 \%$ versus $87 \%, \mathrm{p}<0.001)$, lower rate of VPS

( $49 \%$ versus $85 \%, \mathrm{p}<0.001)$, and lower VPS

correction $(47 \%$ versus $70 \%, \mathrm{p}<0.02)$

MOMS: Management of Myelomeningocele Study. MOMS2: Follow-up of the Management of Myelomeningocele Study.

VPS: ventriculoperitoneal shunt.

(Data obtained from Adzick et al., ${ }^{3}$ Joyeux et al., ${ }^{68}$ Brock et al., ${ }^{48}$ Mazzola et al., ${ }^{6}$ and Houtrow et al. ${ }^{50}$ ). 


\section{POSTNATAL SURGERY OR FETAL SURGERY}

It has been demonstrated that intrauterine damage of the nervous system is progressive. ${ }^{44}$ The "two-hit hypothesis" suggests that an initial lesion occurs, the anatomical defect itself, and then a second lesion due to the ongoing exposure of the nervous tissue to amniotic fluid. ${ }^{45-47}$ Therefore, based on the hypothesis that an early defect closure may be associated with improved postnatal outcomes by reducing exposure of the neural tissue to amniotic fluid for a prolonged time, the concept of prenatal repair was introduced. $3,44,46$

In 2011, the MOMS trial was published, which compared the outcomes of open prenatal surgery and postnatal surgery. ${ }^{3}$ The study was ended early due to the clear benefits observed in the prenatal surgery group, which showed, at the 12-month follow-up, a reduction in VPS requirement $(40 \%$ in the prenatal versus $82 \%$ in the postnatal surgery group; relative risk $[\mathrm{RR}]=0.48 ; 97.7 \%$ confidence interval $[\mathrm{CI}]$ : $0.36-0.64 ; p<0.001$ ) and, at the 30-month followup, an improved composite outcome of mental development and motor function. ${ }^{3}$ In addition, it doubled the ability to walk independently (42\% versus $21 \%, p<0.01$ ) and increased the rate of complete reversal of Chiari II (36\% versus $4 \%, p<0.001)$. Therefore, based on different subsequent series with follow-up until school age, ${ }^{48-50}$ various societies agree that open fetal surgery for myelomeningocele should be offered as a management option (Figure 8).,4-7
Both the MOMS and subsequent series recorded significant maternal morbidity, including uterine dehiscence/ thinning or rupture (35\% in the MOMS) ${ }^{47}$ not only in the index pregnancy, but also in subsequent ones. An international prospective study showed that the risk for uterine rupture in pregnancies after an open surgery for myelomeningocele was $9.6 \%$ $(5 / 52)$, with a median gestational age of 28 weeks (26.0-31.5) and 2 fetal deaths included in the 5 uterine rupture cases. ${ }^{51,52}$ In order to reduce such maternal risks, different groups introduced changes in the original surgery, such as a smaller hysterotomy ${ }^{53,54}$ and fetoscopic surgery for myelomeningocele. ${ }^{55}$

\section{FETAL SURGERY FOR MYELOMENINGOCELE}

\section{a. Inclusion and exclusion criteria}

The typical inclusion and exclusion criteria are described in Table 2. They experienced some changes after the MOMS publication, such as an increase in the upper limit for gestational age (27-28 weeks) or body mass index (> 35 in the MOMS, then increased to 40 ), among others. ${ }^{41,56}$ Recent series described that $40-60 \%$ of cases with a prenatal diagnosis of spina bifida would be candidates for fetal surgery. ${ }^{57,58}$

\section{b. Technical aspects of open fetal surgery}

The surgical technique described in the MOMS is an open surgery consisting in laparotomy, uterine exteriorization, large hysterotomy (6$8 \mathrm{~cm}$ ), exposing the fetus' back for defect closure,

TABLE 2. Inclusion and exclusion criteria of the Management of Myelomeningocele Study (Adzick et al. $)^{3}$

\begin{tabular}{ll}
\hline Inclusion & Exclusion \\
\hline Singleton pregnancy & $\begin{array}{l}\text { Fetal anomaly unrelated to myelomeningocele } \\
\text { Kyphosis }>30 \text { degrees }\end{array}$ \\
$\begin{array}{l}\text { Maternal age } \geq 18 \text { years } \\
\text { Type of lesion: myelomeningocele or myeloschisis }\end{array}$ & $\begin{array}{l}\text { Increased risk for spontaneous preterm birth (history of preterm birth, } \\
\text { short cervix }<20 \mathrm{~mm} \text {, cerclage) or iatrogenic preterm birth } \\
\text { (e.g., uncontrolled HTN, insulin-dependent pregestational diabetes) }\end{array}$ \\
$\begin{array}{l}\text { Placental abnormalities (placenta previa, suspected adhesion disorder) } \\
\text { or uterine abnormalities (e.g., bicornate uterus) }\end{array}$ \\
Besion location: T1-S1 & $\begin{array}{l}\text { Body mass index }>35 \\
\text { Maternal alloimmunization }\end{array}$ \\
Normal karyotype & $\begin{array}{l}\text { Maternal HIV, hepatitis-B or hepatitis-C status positive } \\
\text { Chiari II malformation present }\end{array}$ \\
Able to remain close to the treating center & $\begin{array}{l}\text { Psychosocial limitations } \\
\end{array}$
\end{tabular}

HTN: arterial hypertension; HIV: human immunodeficiency virus. 
and subsequent hysterorrhaphy (Figure 9).,36 The defect closure technique is similar to that used in the postnatal period: identification and separation of the neural placode from the surrounding epithelium, dura mater closure, myofascial closure, and skin closure..$^{59}$

After the MOMS, different groups proposed changes in surgical approach. To reduce the complications of hysterotomy, some centers perform a 3-layer, instead of a 2-layer closure. ${ }^{60}$ The concept of "mini-hysterotomy" was introduced, which measured approximately $3 \mathrm{~cm}$ or less, ${ }^{53,54}$ and alternative instruments were tested, such as using different types of retractors, ${ }^{53}$ including a plastic retractor (Alexis). ${ }^{61}$ Another change was the use of atosiban as a tocolytic agent, which is not available in the USA, but which has been adopted by several centers because it demonstrated to be a better uterine relaxant than magnesium sulphate, with a better safety profile. ${ }^{62-64}$

\section{c. Technical aspects of open fetoscopic surgery}

The fetoscopic approach may be percutaneous ${ }^{65-67}$ or with a laparotomy with uterine exteriorization, ${ }^{5,47,55,68}$ with the use of $2{ }^{69}$
3 (Figure 10) or 4 ports. ${ }^{67}$ Given that fetoscopic techniques are heterogeneous, and in the absence of a randomized trial like the MOMS, fetoscopic repair is still under study. For the purpose of assessing the performance of different fetoscopic techniques, an international consortium was established, the International Fetoscopic Myelomeningocele Repair Consortium. The Argentine members are Hospital Universitario Austral and Hospital Italiano de Buenos Aires.

\section{SOME FREQUENTLY ASKED QUESTIONS IN RELATION TO PERINATAL PROGNOSIS OF PRENATAL SURGERY FOR MYELOMENINGOCELE}

\section{a. Which one is better: open or fetoscopic fetal surgery?}

The technique that has been supported by a randomized clinical trial is the open approach, whereas the fetoscopic strategy is still under study, so it is still not possible to answer this question. ${ }^{47}$ There are approximately 50 centers around the world offering fetal surgery for myelomeningocele. Distribution, approach, and outcomes may be observed in an interactive map of the International Society for Prenatal

FIGURE 9. Open fetal surgery for myelomeningocele. a) Four monofilament traction sutures, 2 on each side, through the full thickness of the uterine wall. $b$-d) Hysterotomy performed to open the membranes, which are fixed with a continuous suture. e-f) Upon administering analgesia and prior fetal paralysis, the fetal defect is exposed and closed by the pediatric neurosurgeon. g) Finally, Ringer's lactate solution is restored with vancomycin to replace lost amniotic fluid and a 2-layer hysterorrhaphy is performed. h) Newborn infant in the reception room; from there, the baby and the mother were taken to the joint hospitalization room.
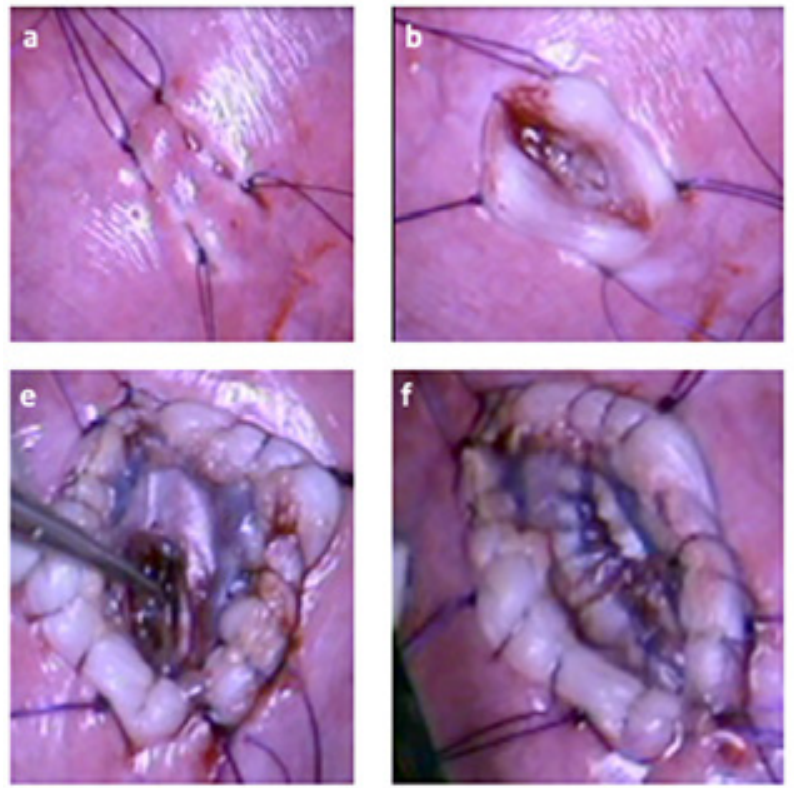
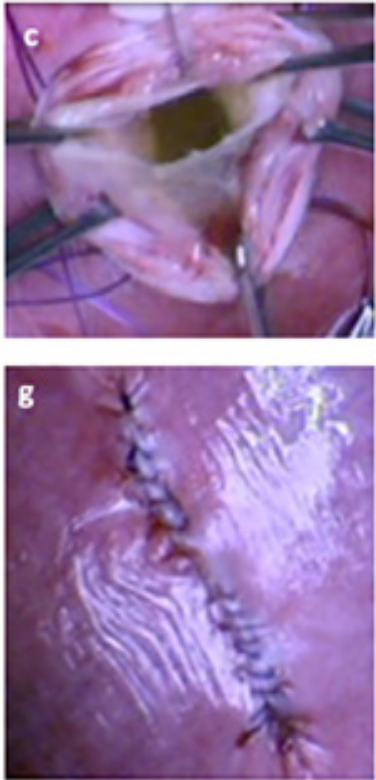
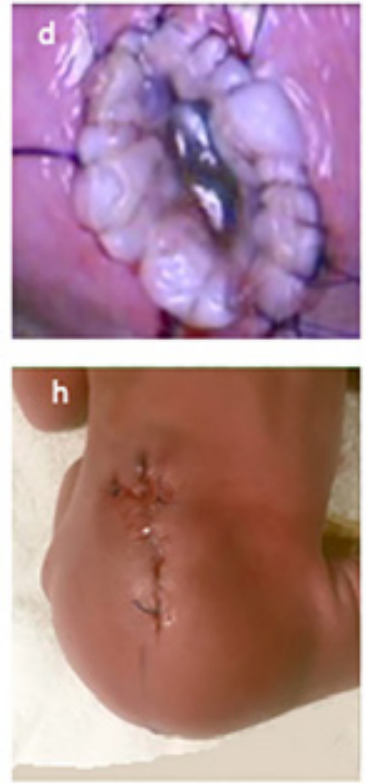
Diagnosis (ISPD) (https: / / ispdhome.org/ISPD/ SIGs/Fetal_Therapy_Map.aspx) (Figure 11). In Argentina, 2 centers have been appointed: Hospital Universitario Austral and Hospital Italiano de Buenos Aires. ${ }^{64,70}$ In addition, outside this registry, the surgery is also performed in Centro de Educación Médica e Investigaciones Clínicas (CEMIC), where, in addition, the first ever fetal surgery for myelomeningocele in Argentina was performed in 2001, with the help of Doctor Michael Harrison from the University of San Francisco, California.
A fetoscopic approach would appear to be more adequate from a maternal perspective if similar (or better) neuroprotection outcomes were demonstrated compared to the open surgery technique. The percutaneous fetoscopic approach is less invasive, but poses several technical challenges, including a very high rate $(30-55 \%$ at $<30$ weeks) of premature rupture of membranes (PROM) and a high preterm birth rate, with a gestational age at birth of 32-33 weeks (Table 3). ${ }^{47}$ However, the fetoscopic approach with uterine exteriorization shows a PROM rate

FIGURE 10. Fetoscopic surgery for myelomeningocele (posterior placenta). After uterine exteriorization, with the fetus in the desired position, 4 membrane fixation points are established, through which the first port is inserted under ultrasound guidance (a). Then, the amniotic fluid is removed and heated, humidified $\mathrm{CO}_{2}$ is introduced. $b$ ) The second and third ports are inserted under fetoscopic guidance. c) Membranes are irrigated every 15 minutes. d) Neurosurgical time. e) Sutured fetal defect.f) Newborn in the reception room.
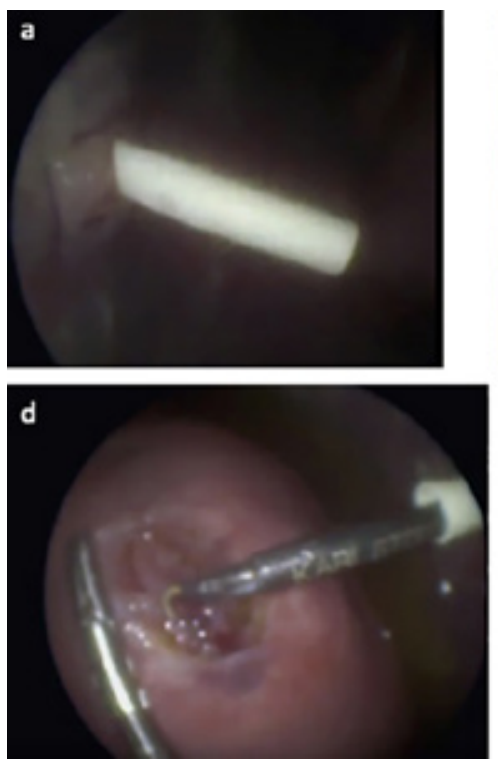
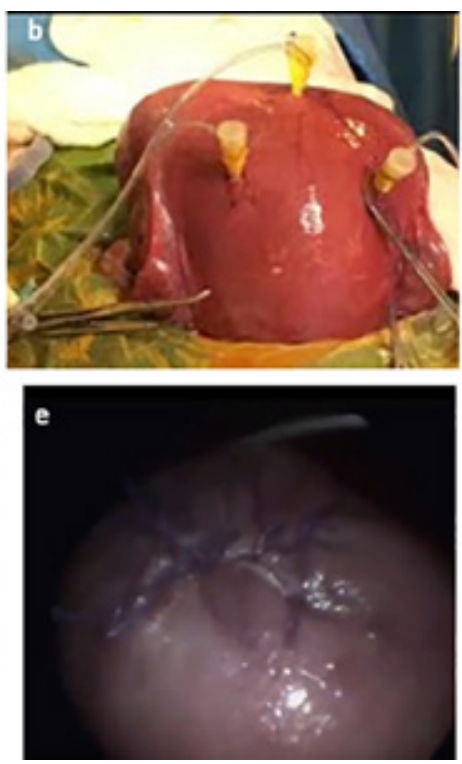
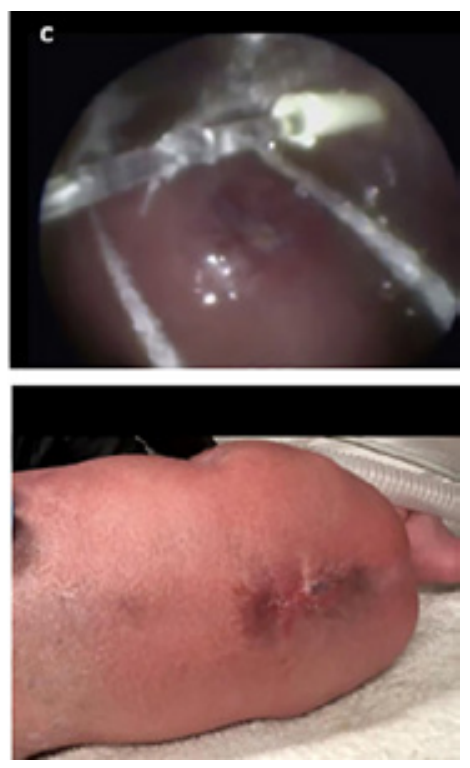

FIGURE 11. Map of centers offering prenatal surgery for myelomeningocele around the world (the interactive version can be found in https://ispdhome.org/ISPD/SIGs/Fetal_Therapy_Map.aspx)

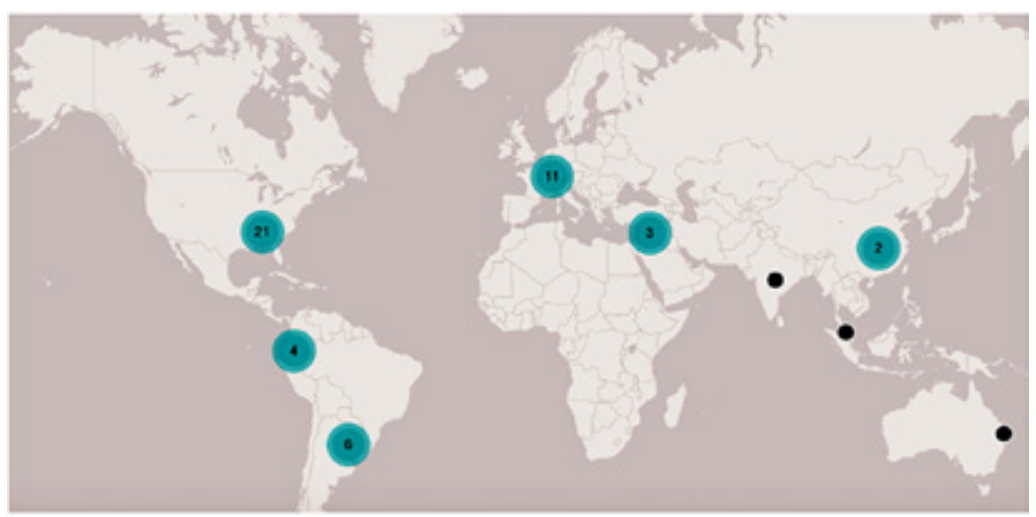


similar to that of the open surgery approach $(\sim 10 \%$ at $<30$ weeks), apparently similar neurological outcomes, and an older gestational age at birth than the open approach. ${ }^{47}$ An associated disadvantage is the greater need for neonatal treatment due to a higher rate of skin dehiscence or cerebrospinal fluid leakage through the wound ${ }^{47}$ although the 3-layer closure, versus single-layer, would reduce such complication (Table 3).

\section{b. Is it possible to reduce the risk for premature rupture of membranes?}

PROM is the Achilles heel of fetal surgery. In the surgery for myelomeningocele, it is possible to reduce the risk for PROM considering some factors:

- Gestational age at the time of surgery: the risk appears to decrease with a longer gestational age at the time of the procedure. Soni et al. ${ }^{71}$

TABLE 3. Characteristics and outcomes of different fetal surgery techniques for myelomeningocele. The numbers are estimations based on studies published by more experienced centers and in reports from conferences, courses or symposiums (adapted from Danzer et al..$^{47}$ and Joyeux et al.). ${ }^{76}$

\begin{tabular}{|c|c|c|c|c|c|c|}
\hline \multirow{2}{*}{ Parameter } & \multirow{2}{*}{$\begin{array}{c}\text { Postnatal surgery } \\
\text { MOMS } \\
\text { Postnatal surgery } \\
\text { group }^{3}\end{array}$} & \multicolumn{3}{|c|}{ Open fetal surgery } & \multicolumn{2}{|c|}{ Fetoscopic fetal surgery } \\
\hline & & $\begin{array}{l}\text { MOMS } \\
\text { Fetal surgery } \\
\text { group }^{3}\end{array}$ & $\begin{array}{c}\text { Standard } \\
\text { hysterotomy } 3,47,57,74,75,77-82\end{array}$ & $\begin{array}{c}\text { Mini- } \\
\text { hysterotomy }\end{array}$ & $\begin{array}{l}\text { Laparotomy- } \\
\text { assisted }^{55,69,85}\end{array}$ & Percutaneus ${ }^{55,65-67,83,84}$ \\
\hline Hysterotomy & - & \multicolumn{2}{|c|}{$6-8 \mathrm{~cm}$} & $2,5-4 \mathrm{~cm}$ & $2-3$ ports & $3-4$ ports \\
\hline Access to uterus & - & \multicolumn{3}{|c|}{ Scalpel incision } & \multicolumn{2}{|c|}{ Seldinger technique, catheter 6 Fr-12 Fr } \\
\hline Layers over placode & \multicolumn{4}{|c|}{$2-3$} & $1-3$ & $1-2$ \\
\hline Mode of delivery & \multicolumn{4}{|c|}{ Elective C-section } & \multicolumn{2}{|c|}{ Vaginal delivery allowed } \\
\hline \multicolumn{7}{|l|}{ Surgical outcomes } \\
\hline Maternal deaths & 0 & 0 & 0 & 0 & 0 & 0 \\
\hline Perinatal deaths & $\begin{array}{c}\sim 2 \% \text { of neonatal } \\
\text { deaths }\end{array}$ & \multicolumn{3}{|c|}{$\begin{array}{c}\approx 0-2 \% \text { of intrauterine } \\
\text { deaths }\end{array}$} & $\begin{array}{c}\approx 2 \% \text { of intrauterine } \\
\text { deaths }\end{array}$ & $\begin{array}{c}2-5 \% \text { of intrauterine } \\
\text { deaths }\end{array}$ \\
\hline PROM < 30 weeks & Not reported & Not reported & $\approx 10 \%$ & $\approx 2 \%$ & $\approx 10 \%$ & $30-55 \%$ \\
\hline GA at birth & 37 weeks & \multicolumn{3}{|c|}{ 34-35 weeks } & 38 weeks & 32-33 weeks \\
\hline$<37$ weeks & $15 \%$ & & $70-80 \%$ & $50-80 \%$ & $30-90 \%$ & $90 \%$ \\
\hline$<30$ weeks & $0 \%$ & & $12-13 \%$ & $0-5 \%$ & $2-25 \%$ & $10-20 \%$ \\
\hline $\begin{array}{l}\text { Uterine thinning } \\
\text { or dehiscence }\end{array}$ & $0 \%$ & & $30-40 \%$ & $5 \%$ & $0 \%$ & $0 \%$ \\
\hline
\end{tabular}

\begin{tabular}{|c|c|c|c|c|c|c|}
\hline \multicolumn{7}{|c|}{ Neuroprotection outcomes } \\
\hline $\begin{array}{l}\text { Postnatal lesion } \\
\text { treatment required }\end{array}$ & $6 \%$ & $13 \%$ & $3-7 \%$ & $9 \%$ & * $6-36 \%$ & $\sim 25 \%$ \\
\hline $\begin{array}{l}\text { Improved neonatal } \\
\text { motor function }\end{array}$ & Not reported & Not reported & $\approx 55 \%$ & $\approx 35 \%$ & $70-80 \%$ & $55-100 \%$ \\
\hline $\begin{array}{l}\text { Complete reversal of } \\
\text { Chiari II at } 12 \text { months }\end{array}$ & $4 \%$ & $36 \%$ & \multicolumn{2}{|c|}{$\approx 70 \%$} & $40-45 \%$ & * $55-95 \%$ \\
\hline VPS at 12 months & $82 \%$ & $44 \%$ & $\approx 40 \%$ & $\approx 40 \%$ & $\approx 40 \%$ & $30-60 \%$ \\
\hline $\begin{array}{l}\wedge \text { Ambulation with } \\
\text { or without assistance }\end{array}$ & $57 \%$ & $71 \%$ & $\approx 70 \%$ & Not reported & $90 \%$ & $70 \%$ \\
\hline
\end{tabular}

VPS: ventriculoperitoneal shunt; MOMS: Management of Myelomeningocele Study;

PROM: premature rupture of membranes; GA: gestational age.

Some groups perform hysterotomies of $1.5 \mathrm{~cm}$ (reported in a symposium and manuscript accepted for publication, Rogelio Cruz Martínez, 2020).

* The group with the most experience in laparotomy-assisted fetal surgery (Texas Children's Hospital) started with a single layer closure and then modified this technique to a 3-layer closure, which reduced the need for postnatal correction of the surgical site and increased the rate of Chiari reversal after 12 months (data reported in the course titled Simulation Training of Fetoscopic Repair of Meningomyelocele, December 14th-15th, 2019, Texas Children's Hospital, Texas, USA).

$\wedge$ Ambulation at 24-30 months independently or with braces and/or crutches versus no ambulation. 
observed a significantly higher PROM rate in open fetal surgery when performed at 20-21 weeks compared to those done after 25 weeks.

- Prevention of chorioamniotic separation: it is one of the main risk factors for preterm birth. ${ }^{72,73}$ Corroenne et al. ${ }^{73}$ analyzed 91 fetal surgeries (52 fetoscopic and 39 open surgeries) and found a $34 \%$ of chorioamniotic separation, with no differences between both approaches. Patients with chorioamniotic separation had a higher risk for PROM (48\% versus $12 \%$, $p<0.01)$ and preterm birth (68\% versus $38 \%, p<0.01)$, and a significant difference was observed between those that showed chorioamniotic separation before 30 weeks (90\% of preterm births) versus those that occurred after 30 weeks (36\%). ${ }^{73}$ In fetoscopic surgeries, it is believed that certain aspects, such as membrane dehydration due to the effect of carbon dioxide $\left(\mathrm{CO}_{2}\right)$, could play a role; for this reason, a common practice now is to use humidified $\mathrm{CO}_{2}$ and hydrate the membranes every 15 minutes (Figure 10) or to separate the membranes during port insertion, so it was proposed to have 4 fixation points of the membranes to the myometrium for each port, instead of 2 (Figure 10). ${ }^{73}$ c. What are the prognostic factors for VPS requirement in fetuses subjected to prenatal surgery?

Several predictors of VPS requirement in the first year of life have been described. ${ }^{25}$ The most significant ones are severe preoperative ventriculomegaly (>15 mm), persistent Chiari II malformation in the FMRI 6 weeks after surgery, and a higher than expected increase in ventricle volume after surgery (Figure 12). ${ }^{25}$

\section{d. Is severe ventriculomegaly a contraindication to fetal surgery?}

No. Although no reduction in VPS requirement has been observed in the fetuses with ventriculomegaly $>15 \mathrm{~mm}$ subjected to surgery, the benefits in relation to motor function may be maintained. ${ }^{25,47,74,75}$

\section{CONCLUSIONS}

In recent years, the presence of indirect signs of myelomeningocele as a screening method has allowed to increase prenatal detection by making a diagnosis at an earlier gestational age. An optimal management of myelomeningocele patients includes a timely prenatal diagnosis, adequate pre- and postnatal follow-up, and, in selected cases, an optional fetal surgery.

FIGURE 12. MRI and volumetric ventricular 3D reconstruction with intrauterine myelomeningocele repair that did not require and did require VPS. Before surgery, case 1 had mild ventriculomegaly (12 mm), Chiari II malformation, grade 3 (a). b) Six weeks after surgery. Evidence of Chiari resolution and ventricular growth of $3 \mathrm{~mL} /$ week. In this case, no VPS was required. However, before surgery, case 2 had severe ventriculomegaly $(17 \mathrm{~mm})$, Chiari II malformation, grade 3 (a). Six weeks after surgery $(b)$, evidence of persistent obliteration of CSF spaces of the posterior fossa and ventricular growth of $15 \mathrm{~mL} /$ week. In this case, a VPS was placed. VPS: ventriculoperitoneal shunt.

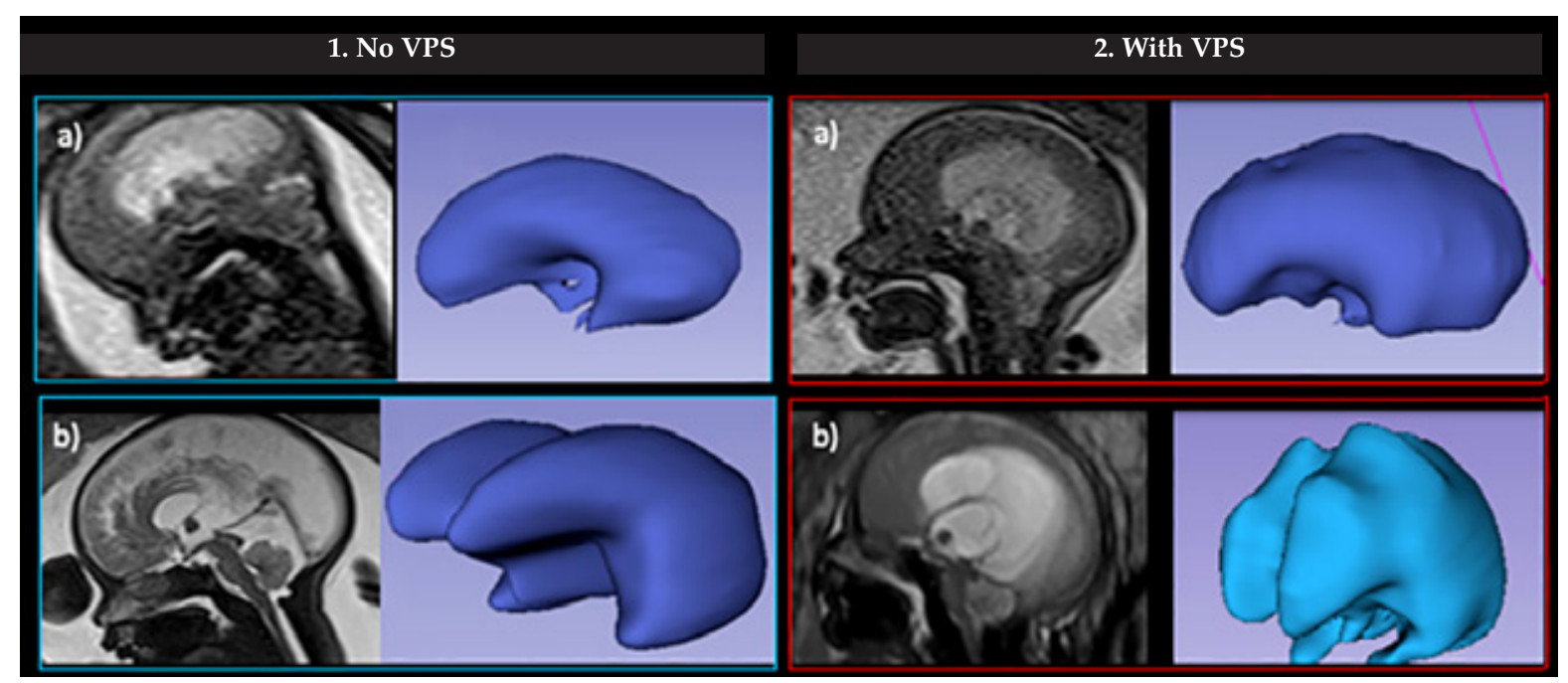


Although traditional open fetal surgery has shown benefits, it is associated with maternal risks that should be taken into consideration. Fetoscopic surgery has fewer maternal risks and is not a contraindication to vaginal delivery; however, fetoscopic techniques vary and outcomes are heterogeneous and still under study. Most likely, in the coming years, more adequate techniques that combine the greatest fetal benefits and the fewest maternal risks will be defined.

\section{Acknowledgments}

We would like to thank Alejandro FigarGutiérrez, Alejo Adrover, Daniel Deluca Bisurgi, and Gustavo García Fornari (Department of Anesthesiology), Micaela Iglesias and Maximiliano Arias (Department of Obstetrics), Carina Maineri (Department of Pediatric Neurosurgery), Mariano Uzal (Department of Gynecology), Cristina Cortines (Department of Pediatrics and Myelomeningocele Clinic), Facundo Nahuel Díaz and Marcelo Pietrani (Department of Imaging Studies), Carolina Giudice, Silvia Fernández Jonusas, and Gonzalo Mariani (Department of Neonatology) for their help with the development and operation of the Fetal Myelomeningocele Surgery Program of Hospital Italiano de Buenos Aires.

\section{REFERENCES}

1. Wilson RD;SOGCGenetics Committee;SpecialContributor. Prenatal screening, diagnosis, and pregnancy management of fetal neural tube defects. J Obstet Gynaecol Can. 2014; 36(10):927-39.

2. Committee on Practice Bulletins-Obstetrics. Practice Bulletin No. 187: Neural Tube Defects. Obstet Gynecol. 2017; 130(6):e279-90.

3. Adzick NS, Thom EA, Spong CY, Brock JW $3^{\text {rd }}$, et al. A randomized trial of prenatal versus postnatal repair of myelomeningocele. N Engl J Med. 2011; 364(11):993-1004.

4. Bauer DF, Beier AD, Nikas DC, Assassi N, et al. Congress of NeurologicalSurgeons Systematic Review and EvidenceBased Guideline on the Management of Patients With Myelomeningocele: Whether Prenatal or Postnatal Closure Affects Future Ambulatory Status. Neurosurgery. 2019; 85(3):E409-11.

5. Kabagambe SK, Jensen GW, Chen YJ, Vanover MA, et al. Fetal Surgery for Myelomeningocele: A Systematic Review and Meta-Analysis of Outcomes in Fetoscopic versus Open Repair. Fetal Diagn Ther. 2018; 43(3):161-74.

6. Mazzola CA, Assassi N, Baird LC, Bauer D, et al. Congress of NeurologicalSurgeons Systematic Review and EvidenceBased Guidelines for Pediatric Myelomeningocele: Executive Summary. Neurosurgery. 2019; 85(3):299-301.

7. Tamber MS, Flannery AM, McClung-Smith C, Assassi $\mathrm{N}$, et al. Congress of Neurological Surgeons Systematic Review and Evidence-Based Guideline on the Incidence of Shunt-Dependent Hydrocephalus in Infants With Myelomeningocele After Prenatal Versus Postnatal Repair.
Neurosurgery. 2019; 85(3):E405-8

8. Sargiotto C, Bidondo MP, Liascovich $\mathrm{R}$, Barbero $\mathrm{P}$, et al. Descriptive study on neural tube defects in Argentina. Birth Defects Res A Clin Mol Teratol. 2015; 103(6):509-16.

9. Campaña H, Pawluk MS, López Camelo JS; Grupo de Estudio del ECLAMC. Prevalencia al nacimiento de 27 anomalías congénitas seleccionadas, en 7 regiones geográficas de la Argentina. Arch Argent Pediatr. 2010; 108(5):409-17.

10. RENAC. Reporte Anual 2018: Análisis epidemiológico sobre las anomalías congénitas en recién nacidos, registradas durante 2017 en la República Argentina. [Accessed on: August 24 ${ }^{\text {th }}, 2020$ ]. Available at: http:/ / www.anlis.gov.ar/cenagem / wp-content / uploads / 2018/12 / 1-REPORTE-RENAC2018-formato-web.pdf.

11. Bianchi D, Crombleholme TM, D'Alton ME, Malone FD. Myelomeningocele. In: Fetology: Diagnosis and Management of the Fetal Patient. $2^{\text {nd }}$ ed. Hong Kong: McGraw-Hill Education; 2010.Pages 151-65.

12. Timbolschi D, Schaefer E, Monga B, Fattori D, et al. Neural tube defects: the experience of the registry of congenital malformations of Alsace, France, 1995-2009. Fetal Diagn Ther. 2015; 37(1):6-17.

13. EUROCAT. European network of population-based registries for the epidemiological surveillance of congenital anomalies. Prenatal detection rates charts and tables. [Accessed on: July 20 $\left.0^{\text {th }}, 2020\right]$. Available at: https: / / eu-rdplatform.jrc.ec.europa.eu/eurocat/eurocat-data/prenatalscreening-and-diagnosis_en.

14. Campaña H, Ermini M, Aiello HA, Krupitzki H, et al. Prenatal sonographic detection of birth defects in 18 hospitals from South America. J Ultrasound Med. 2010; 29(2):203-12

15. Campbell S, Pryse-Davies J, Coltart TM, Seller MJ, et al. Ultrasound in the diagnosis of spina bifida. Lancet. 1975; 1(7915):1065-8

16. Wald NJ, CuckleH, BrockJH, Peto R, et al. Maternal serumalpha-fetoprotein measurement in antenatal screening for anencephaly and spina bifida in early pregnancy. Report of U.K. collaborative study on alpha-fetoprotein in relation to neural-tube defects. Lancet. 1977; 1(8026):1323-32.

17. Chaoui R, Benoit B, Mitkowska-Wozniak H, Heling KS, et al. Assessment of intracranial translucency (IT) in the detection of spina bifida at the 11-13-week scan. Ultrasound Obstet Gynecol. 2009; 34(3):249-52.

18. Rossi AC, PrefumoF. Accuracy of ultrasonography at 11-14 weeks of gestation for detection of fetal structural anomalies: a systematic review. Obstet Gynecol. 2013; 122(6):1160-17.

19. Van Mieghem T, Hindryckx A, Van Calsteren K. Early fetal anatomy screening: who, what, when and why? Curr Opin Obstet Gynecol. 2015; 27(2):143-50.

20. Salomon LJ, Alfirevic Z, Berghella V, Bilardo C, et al. Practice guidelines for performance of the routine midtrimester fetal ultrasound scan. Ultrasound Obstet Gynecol. 2011; 37(1):116-26.

21. International Society of Ultrasound in Obstetrics \& Gynecology Education Committee. Sonographic examination of the fetal central nervous system: guidelines for performing the 'basic examination' and the 'fetal neurosonogram'. Ultrasound Obstet Gynecol. 2007;29(1):10916.

22 Nicolaides KH, Campbell S, Gabbe SG, Guidetti R. Ultrasound screening for spina bifida: cranial and cerebellar signs. Lancet. 1986; 2(8498):72-4.

23. Van den Hof MC, Nicolaides KH, Campbell J, Campbell S. Evaluation of the lemon and banana signs in one hundred thirty fetuses with open spina bifida. Am J Obstet Gynecol. 
1990; 162(2):322-7.

24. Sepulveda W, Wong AE, Sepulveda F, Alcalde JL, et al. Prenatal diagnosis of spina bifida: from intracranial translucency to intrauterine surgery. Childs Nerv Syst. 2017; 33(7):1083-99.

25. Zarutskie A, Guimaraes C, Yepez M, Torres P, et al. Prenatal brain imaging for predicting need for postnatal hydrocephalus treatment in fetuses that had neural tube defect repair in utero. Ultrasound Obstet Gynecol. 2019; 53(3):324-34.

26. Meller C, Aiello H, Otaño L. Sonographic detection of open spina bifida in the first trimester: review of the literature. Childs Nerv Syst. 2017; 33(7):1101-6.

27. Engels AC, Joyeux L, Brantner C, De Keersmaecker B, et al. Sonographic detection of central nervous system defects in the first trimester of pregnancy. Prenat Diagn. 2016; 36(3):266-73.

28. Garcia-Posada R, Eixarch E, Sanz M, Puerto B, et al. Cisterna magna width at 11-13 weeks in the detection of posterior fossa anomalies. Ultrasound Obstet Gynecol. 2013; 41(5):51520.

29. Iuculano A, Zoppi MA, Piras A, Arras M, et al. Brain stem/ brain stem occipital bone ratio and the four-line view in nuchal translucency images of fetuses with open spina bifida. J Matern Fetal Neonatal Med. 2014;1-4.

30. Kappou D, Papastefanou I, Pilalis A, Kavalakis I, et al. Towards detecting open spina bifida in the first trimester: the examination of the posterior brain. Fetal Diagn Ther. 2015; 37(4):294-300.

31. Lachmann R, Chaoui R, Moratalla J, Picciarelli G, et al. Posterior brain in fetuses with open spina bifida at 11 to 13 weeks. Prenat Diagn. 2011; 31(1):103-6.

32. Sebire NJ, Noble PL, Thorpe-Beeston JG, Snijders RJ, et al. Presence of the 'lemon' sign in fetuses with spina bifida at the 10-14-week scan. Ultrasound Obstet Gynecol. 1997; 10(6):403-5.

33. Karl K, Benoit B, Entezami M, Heling KS, et al. Small biparietal diameter in fetuses with spina bifida on 11-13week and mid-gestation ultrasound. Ultrasound Obstet Gynecol. 2012; 40(2):140-4.

34. Bernard JP, Cuckle HS, Stirnemann JJ, Salomon LJ, et al. Screening for fetal spina bifida by ultrasound examination in the first trimester of pregnancy using fetal biparietal diameter. Am J Obstet Gynecol. 2012; 207(4):306.e1-5.

35. Simon EG, Arthuis CJ, Haddad G, Bertrand P, et al. Biparietal/transverse abdominal diameter ratio $\leq 1$ : potential marker for open spina bifida at 11-13-week scan. Ultrasound Obstet Gynecol. 2015; 45(3):267-72.

36. Loureiro T, Ushakov F, Montenegro N, Gielchinsky Y, et al. Cerebral ventricular system in fetuses with open spina bifida at 11-13 weeks' gestation. Ultrasound Obstet Gynecol. 2012; 39(6):620-4.

37. Finn M, Sutton D, Atkinson S, Ransome K, et al. The aqueduct of Sylvius: a sonographic landmark for neural tube defects in the first trimester. Ultrasound Obstet Gynecol. 2011; 38(6):640-5.

38. Buisson O, De Keersmaecker B, Senat MV, Bernard JP, et al. Sonographic diagnosis of spina bifida at 12 weeks: heading towards indirect signs. Ultrasound Obstet Gynecol. 2002; 19(3):290-2.

39. Shaer CM, Chescheir N, Schulkin J. Myelomeningocele: a review of the epidemiology, genetics, risk factors for conception, prenatal diagnosis, and prognosis for affected individuals. Obstet Gynecol Surv. 2007; 62(7):471-9.

40. Donnelly JC, Platt LD, Rebarber A, Zachary J, et al. Association of copy number variants with specific ultrasonographically detected fetal anomalies. Obstet Gynecol. 2014; 124(1):83-90.
41. Moise KJ Jr, Moldenhauer JS, Bennett KA, Goodnight W, et al. Current Selection Criteria and Perioperative Therapy Used for Fetal Myelomeningocele Surgery. Obstet Gynecol. 2016; 127(3):593-7.

42. Carreras E, Maroto A, Illescas T, Meléndez M, et al. Prenatal ultrasound evaluation of segmental level of neurological lesion in fetuses with myelomeningocele: development of a new technique. Ultrasound Obstet Gynecol. 2016;47(2):1627.

43. Sutton LN, Adzick NS, Bilaniuk LT, Johnson MP, et al. Improvement in hindbrain herniation demonstrated by serial fetal magnetic resonance imaging following fetal surgery for myelomeningocele. JAMA. 1999; 282(19):182631.

44. Corroenne R, Yepez M, Pyarali M, Foxk, et al. Longitudinal evaluation of motor function in patients who underwent a prenatal or postnatal neural tube defect repair. Ultrasound Obstet Gynecol. 2020;10.1002/uog.22165. [In press].

45. Heffez DS, Aryanpur J, Hutchins GM, Freeman JM. The paralysis associated with myelomeningocele: clinical and experimental data implicating a preventable spinal cord injury. Neurosurgery. 1990; 26(6):987-92.

46. Blumenfeld YJ, Belfort MA. Updates in fetal spina bifida repair. Curr Opin Obstet Gynecol. 2018; 30(2):123-9.

47. Danzer E, Joyeux L, Flake AW, Deprest J. Fetal surgical intervention for myelomeningocele: lessons learned, outcomes, and future implications. Dev Med Child Neurol. 2020; 62(4):417-25.

48. Brock JW $3^{\text {rd }}$, Thomas JC, Baskin LS, Zderic S, et al. Effect of Prenatal Repair of Myelomeningocele on Urological Outcomes at School Age. J Urol. 2019; 202(4):812-8.

49. Inversetti A, Van der Veeken L, Thompson D, Jansen K, et al. Neurodevelopmental outcome of children with spina bifida aperta repaired prenatally vs postnatally: systematic review and meta-analysis. Ultrasound Obstet Gynecol. 2019; 53(3):293-301.

50. Houtrow AJ, Thom EA, Fletcher JM, Burrows P, et al. Prenatal Repair of Myelomeningocele and School-age Functional Outcomes. Pediatrics. 2020; 145(2):e20191544.

51. Goodnight WH, Bahtiyar O, Bennett KA, Emery S, et al. Subsequent pregnancy outcomes after open maternal-fetal surgery for myelomeningocele. Am J Obstet Gynecol. 2019; 220(5):494.e1-7.

52. Chmait RH, Kontopoulos EV, Quintero RA. Uterinelegacy of open maternal-fetal surgery: preterm uterine rupture. Am J Obstet Gynecol. 2019; 221(5):535.

53. Botelho RD, Imada V, Da Costa KJR, Watanabe LC, etal. Fetal Myelomeningocele Repair through a Mini-Hysterotomy. Fetal Diagn Ther. 2017; 42(1):28-34.

54. Peralta CFA, Botelho RD, Romano ER, Imada V, et al. Fetal open spinal dysraphism repair through a mini-hysterotomy: Influence of gestational age at surgery on the perinatal outcomes and postnatal shunt rates. Prenat Diagn. 2020; 40(6):689-97.

55. Sanz Cortes M, Lapa DA, Acacio GL, Belfort M, et al. Proceedings of the First Annual Meeting of the International Fetoscopic Myelomeningocele Repair Consortium. Ultrasound Obstet Gynecol. 2019; 53(6):855-63.

56. Moldenhauer JS, Flake AW. Open fetal surgery for neural tube defects. Best Pract Res Clin Obstet Gynaecol. 2019;58:12132.

57. AlRefai A, Drake J, Kulkarni AV, Connor K, et al. Fetal myelomeningocele surgery: Only treating the tip of the iceberg. Prenat Diagn. 2019; 39(1):10-5.

58. PanET, PallapatiJ, Krueger A, YepezM, etal.Evaluation and Disposition of Fetal Myelomeningocele Repair Candidates: A Large Referral Center Experience. Fetal Diagn Ther. 2020; 47(2):115-22. 
59. Gupta N. Surgical techniques for open fetal repair of myelomeningocele. Childs Nerv Syst. 2017; 33(7):1143-8.

60. Zaretsky MV, Liechty KW, Galan HL, Behrendt N et al. Modified Hysterotomy Closure Technique for Open Fetal Surgery. Fetal Diagn Ther. 2018; 44(2):105-11.

61. Corral E, Sepulveda W, Ravera F, Muller J, et al. Use of plastic wound retractor at hysterotomy site in prenatal repair of myelomeningocele: a new technique. J Matern Fetal Neonatal Med. 2020; 33(17):3010-5.

62. Ochsenbein-Kölble N, Krähenmann F, Hüsler M, Meuli $\mathrm{M}$, et al. Tocolysis for in utero Surgery: Atosiban Performs Distinctly Better than Magnesium Sulfate. Fetal Diagn Ther. 2018; 44(1):59-64.

63. Vercauteren $M$, Palit $S$, Soetens F, Jacquemyn $Y$, et al. Anaesthesiological considerations on tocolytic and uterotonic therapy in obstetrics. Acta Anaesthesiol Scand. 2009; 53(6):701-9.

64. Figar Gutiérrez A, Adrover A, Deluca D, Alvarez Calzaretta $\mathrm{L}$, et al. Peri-operative considerations for in utero repair of myelomeningocele. Int J Obstet Anesth. 2019; 37:135-6.

65. Kohl T. Percutaneous minimally invasive fetoscopic surgery for spina bifida aperta. Part I: surgical technique and perioperative outcome. Ultrasound Obstet Gynecol. 2014; 44(5):515-24.

66. Degenhardt J, Schürg R, Winarno A, Oehmke F, et al. Percutaneous minimal-access fetoscopic surgery for spina bifida aperta. Part II: maternal management and outcome. Ultrasound Obstet Gynecol. 2014; 44(5):525-31.

67. Lapa DA. Endoscopic fetal surgery for neural tube defects. Best Pract Res Clin Obstet Gynaecol. 2019; 58:133-41.

68. Joyeux L, Danzer E, Flake AW, Deprest J. Fetal surgery for spina bifida aperta. Arch Dis Child Fetal Neonatal Ed. 2018; 103(6):F589-95.

69. Belfort MA, Whitehead WE, Shamshirsaz AA, Bateni ZH, et al. Fetoscopic open neural tube defect repair: development and refinement of a two-port, carbon dioxide insufflation technique. Obstet Gynecol. 2017; 129(4):734-43.

70. Etchegaray A, Palma F, De Rosa R, Russo RD, et al. Cirugía fetal de mielomeningocele: Evolución obstétrica y resultados perinatales a corto plazo de una cohorte de 21 casos. Surg Neurol Int. 2018; 9(Suppl 4):S73-84.

71. Soni S, Moldenhauer JS, Spinner SS, Rendon N, et al. Chorioamniotic membrane separation and preterm premature rupture of membranes complicating in utero myelomeningocele repair. Am J Obstet Gynecol. 2016; 214(5):647.e1-7.

72. Kahr MK, Winder F, Vonzun L, Meuli M, et al. Risk Factors for Preterm Birth following Open Fetal Myelomeningocele Repair: Results from a Prospective Cohort. Fetal Diagn Ther. 2020; 47(1):15-23.

73. Corroenne R, Yepez M, Barth J, Pan E, et al. Chorioamniotic membrane separation following fetal myelomeningocele repair: incidence, risks factors and impact on perinatal outcome. Ultrasound Obstet Gynecol. 2020; 56(5):684-93.

74. Tulipan N, Wellons JC $3^{\text {rd }}$, Thom EA, Gupta N, et al. Prenatal surgery for myelomeningocele and the need for cerebrospinal fluid shunt placement. J Neurosurg Pediatr. 2015; 16(6):613-20.

75. Farmer DL, Thom EA, Brock JW $3^{\text {rd }}$, Burrows P, et al. The Management of Myelomeningocele Study: full cohort 30-month pediatric outcomes. Am J Obstet Gynecol. 2018; 218(2):256.e1-13

76. Joyeux L, De Bie F, Danzer E, Russo FM, et al. Learning curves of open and endoscopic fetal spina bifida closure: systematic review and meta-analysis. Ultrasound Obstet Gynecol. 2020; 55(6):730-9.

77. Johnson MP, Bennett KA, Rand L, Burrows PK, et al. Management of Myelomeningocele Study I. The Management of Myelomeningocele Study: obstetrical outcomes and risk factors for obstetrical complications following prenatal surgery. Am J Obstet Gynecol. 2016; 215(6):778.e1-9.

78. Zamlyniski J, Olejek A, Bohosiewicz J, Bodzek P, et al. [Perinatal results of intrauterine open fetal surgery of fetuses diagnosed with myelomeningocoele-the clinical report of ten cases]. Ginekol Pol. 2007; 78(8):647-51.

79. Moldenhauer JS, Soni S, Rintoul NE, Spinner SS, et al. Fetal myelomeningocele repair: the post-MOMS experience at the Children's Hospital of Philadelphia. Fetal Diagn Ther. 2015; 37(3):235-40.

80. Hisaba WJ, Cavalheiro S, Almodim CG, Borges CP, et al. Intrauterine myelomeningocele repair postnatal results and follow-up at 3.5 years of age-initial experience from a single reference service in Brazil. Childs Nerv Syst. 2012; 28(3):461-7.

81. Bruner JP, Tulipan N, Paschall RL, Boehm FH, et al. Fetal surgery for myelomeningocele and the incidence of shuntdependent hydrocephalus. JAMA. 1999; 282(19):1819-25.

82. Bennett KA, Carroll MA, Shannon CN, Braun SA, et al. Reducing perinatal complications and preterm delivery for patients undergoing in utero closure of fetal myelomeningocele: further modifications to the multidisciplinary surgical technique. J Neurosurg Pediatr. 2014; 14(1):108-14.

83. Verbeek RJ, Heep A, Maurits NM, Cremer R, et al. Fetal endoscopicmyelomeningoceleclosure preserves segmental neurological function. Dev Med Child Neurol. 2012;54(1):1522.

84. Pedreira DAL, Acacio GL, Gonçalves RT, Sá RAM, et al. Percutaneous fetoscopic closure of large open spina bifida using a bilaminar skin substitute. Ultrasound Obstet Gynecol. 2018; 52(4):458-66.

85. Baschat AA, Ahn ES, Murphy J, Miller JL. Fetal blood gas values during fetoscopic myelomeningocele repair performed under carbon dioxide insufflation. Ultrasound Obstet Gynecol. 2018; 52(3):400-2. 